\title{
Effects of UV radiation and consumers on recruitment and succession of a marine macrobenthic community
}

\author{
Heike K. Lotze ${ }^{1,2, *}$, Boris Worm ${ }^{1,2}$, Markus Molis ${ }^{2}$, Martin Wahl ${ }^{2,3}$ \\ ${ }^{1}$ Department of Biology, Dalhousie University, 1355 Oxford Street, B3H 4J1 Halifax, Nova Scotia, Canada \\ ${ }^{2}$ Institut für Meereskunde, Düsternbrooker Weg 20, 24105 Kiel, Germany \\ ${ }^{3}$ University of Namibia, Private Bag 13301, Windhoek, Namibia
}

\begin{abstract}
The combined and interactive effects of climatic and ecological factors are rarely considered in marine communities. We designed a factorial field experiment to analyze (1) the interactive effects of ambient UV radiation and consumers; and (2) the effects of photosynthetically active radiation (PAR 400 to $700 \mathrm{~nm}$ ), UVA (320 to $400 \mathrm{~nm}$ ) and UVB (280 to $320 \mathrm{~nm}$ ) radiation on a marine hard-bottom community in Nova Scotia, NW Atlantic. Species recruitment and succession on ceramic tiles were followed for 5 mo. We found strong negative UV effects on biomass and cover of the early colonizing macroalga Pilayella littoralis, whereas UVB was more harmful than UVA radiation. Consumers, mainly gammarid amphipods, increased $P$. littoralis biomass when UV was excluded, probably through fertilization. These initially strong and interacting UV and consumer effects on total biomass and cover diminished as species succession progressed. Species diversity was not affected by experimental treatments, but significant shifts in species composition occurred, especially at the recruitment stage. Red algae were most inhibited by UV, whereas sedentary invertebrates and some brown algae tended to increase under UV exposure. Consumers suppressed green and filamentous brown algae, but favored the other groups. Again, these effects diminished during the later stages of succession. We conclude that UV radiation can be a significant structuring force in early successional benthic communities, and that consumers can mediate its effects.
\end{abstract}

KEY WORDS: Early life stages · UV stress · Grazing $\cdot$ Recruitment $\cdot$ Productivity $\cdot$ Community structure $\cdot$ Species-specific sensitivity · Rocky shore

Resale or republication not permitted without written consent of the publisher

\section{INTRODUCTION}

Since the discovery of ozone depletion and accompanying increases in UVB radiation (Crutzen 1992, Kerr \& McElroy 1993), much research has focused on potentially harmful effects of UVB on plants and animals. UVB radiation can inhibit photosynthetic processes and damage DNA even at ambient levels, thereby decreasing species performance and survival (Franklin \& Forster 1997, Beardall et al. 1998). UVA radiation, although less damaging, might cause even stronger inhibitions than UVB because of its naturally higher

*Email: heike.lotze@dal.ca fluxes (Cullen \& Neale 1994). Earlier studies predicted strong reductions in primary productivity in terrestrial and aquatic ecosystems under elevated UVB (reviewed in Franklin \& Forster 1997, Searles et al. 2001). However, accumulating knowledge on adaptations, protective and repair mechanisms, and more relevant field studies suggested that the long-term effects of increasing UVB radiation on primary productivity might be less pronounced than previously thought (Vincent \& Roy 1993, Searles et al. 2001).

However, in addition to effects on primary productivity, UV radiation (UVR = UVB + UVA) may alter species composition and species interactions, with consequences for community structure, food web processes and ecosystem functions such as nutrient cycling 
(Bothwell et al. 1994, Franklin \& Forster 1997, Rozema et al. 1997, Searles et al. 2001). For example, changes in UVR could affect depth zonation of benthic macroalgae, because deep-water algae are usually more sensitive to UVR than intertidal species (Larkum \& Wood 1993, Hanelt et al. 1997b, Bischof et al. 1998). Shifts in species composition can occur because of speciesspecific or life stage-specific sensitivities: juvenile life stages were shown to be more vulnerable to UVR than adult macroalgae, and optically thin species were more affected than leathery seaweeds (Dring et al. 1996a,b, Hanelt et al. 1997a,b). UV-induced changes in chemical or pigment content in plants may alter plantherbivore relationships (Döhler et al. 1995, Cronin \& Hay 1996, Pavia et al. 1997, Rozema et al. 1997). Furthermore, differential sensitivities of plants and herbivores towards UVR can lead to strong UV-effects on plant-herbivore interactions as shown for freshwater systems (Bothwell et al. 1994).

Knowledge about UVR effects on species composition and species interactions in the ocean, especially the marine benthos, is scant (but see Pavia et al. 1997, Santas et al.1998a,b). Moreover, the combined and interactive effects of UVR and consumers on community structure have not been studied experimentally in the marine environment. Interactions between climatic and ecological factors were recently shown to be important drivers in macroalgal recruitment (Lotze \& Worm 2002). This means that the impacts of climate change and ecological change, e.g. consumer pressure, need to be studied in combination in order to assess potential interactions and to understand the consequences of multiple human impacts on marine ecosystems (Lotze \& Worm 2002).

Here, we address the single and interactive impacts of ambient UVR and consumers on the structure and productivity of a marine, shallow water, hard-bottom community. In factorial field experiments, we asked how recruitment and succession of macroalgae and sessile invertebrates are affected by: (1) the interactive effects of UVR and consumers; and (2) the differential effects of PAR, UVA and UVB.

\section{MATERIALS AND METHODS}

Experimental site. Our study site was in Duncan's Cove, Nova Scotia, Canada ( $\left.44^{\circ} 29.9^{\prime} \mathrm{N}, 63^{\circ} 31.7^{\prime} \mathrm{W}\right)$, a small, wave-sheltered embayment on the open NW Atlantic coast. The substratum consists of granite bedrock, boulder fields, sand and gravel. The hardbottom communities are dominated by rockweeds (fucoids) and kelps (laminarians) associated with a diverse community of epiphytic and epilithic flora and fauna as well as mobile consumers (Worm 2000). Mea- surements from a nearby long-term monitoring station (Sambro Harbor, $44^{\circ} 27.2^{\prime} \mathrm{N}, 63^{\circ} 35.7^{\prime} \mathrm{W}$ ) indicated that annual water temperatures in recent years fluctuated between -1 and $20^{\circ} \mathrm{C}$ with maxima in August and September (Keizer et al. 1996). Salinity fluctuated between 29 and 32 PSU depending on precipitation. Water column nutrients reached maximum winter concentrations of $3 \mu \mathrm{mol} \mathrm{l}^{-1}$ ammonium, $5.9 \mu \mathrm{mol} \mathrm{l}^{-1}$ nitrate, $0.9 \mu \mathrm{mol} \mathrm{l}^{-1}$ phosphate and $7 \mu \mathrm{mol} \mathrm{l}^{-1}$ silicate, and were depleted and close to the detection limit during the summer months (Keizer et al. 1996). Chlorophyll a (chl a) maxima of 4 to $8 \mu \mathrm{g} \mathrm{l}^{-1}$ were found during spring phytoplankton blooms in March to April (Keizer et al. 1996).

Experimental design and setup. We designed a factorial field experiment to test for the effects of consumers and UVR on the recruitment and development of marine macroalgae and invertebrates. Two subexperiments were run. (1) Effects of consumers (3 levels) and UVR ( 2 levels) were manipulated in a factorial design with 6 replicates, altogether 36 experimental units ('consumer and UVR effects' hereafter). Consumers were either present (open cage) or absent (closed cage), and a partly open cage (half cage) served as a cage control treatment. UVR was manipulated using cut-off filters blocking all UVR $<400 \mathrm{~nm}$ (PAR treatment, 400 to $700 \mathrm{~nm}$ ) or allowing UVR transmittance (PAR + UVA + UVB treatment, 280 to $700 \mathrm{~nm}$ ). (2) Differential effects of PAR, UVA and UVB radiation ('radiation effects' hereafter) were addressed with 4 treatments and 6 replicates (24 experimental units). Cut-off filters were used to block out different spectra of the solar radiation (PAR, PAR + UVA, PAR + UVA + UVB treatments, see next subsection), and a treatment without filter (Full sunlight) served as a filter control treatment.

The field experiment was run from 25 May to 15 October 2001. Six rafts $(110 \times 50 \times 0.5 \mathrm{~cm})$ made from black polyethylene with a wooden frame were moored $15 \mathrm{~m}$ off shore in couples of 2 rafts per mooring. Distance between individual moorings was $20 \mathrm{~m}$. Due to tides, wind and water motion, rafts constantly circulated around their axis. Styrofoam panels provided buoyancy and kept rafts $4 \mathrm{~cm}$ above water surface. Transparent polycarbonate containers $(12 \times$ $12 \mathrm{~cm}$ wide and $10 \mathrm{~cm}$ deep) were cut open at all 4 sites $(10 \times 8 \mathrm{~cm}$ openings $)$ and fixed into holes in the raft surface. Containers had either all sides left open, providing free access for consumers (open cage), or 1 side left open and 3 sides closed with $1 \mathrm{~mm}$ (diagonal diameter) transparent polyethylene mesh (half cage), or all 4 sides closed with mesh (closed cage). Cut-off filters for the UVR treatments (for specifications see next subsection) were positioned above containers and fixed to the rafts. Consumer and UVR treatments were assigned to 
individual rafts using a randomized block design. Each raft represented 1 block containing 1 replicate of each treatment combination. There were 8 experimental units per raft. Rafts, containers and filters were brushcleaned bi-weekly to prevent fouling. Sterilized ceramic tiles $(7 \times 7 \mathrm{~cm}$, unglazed side) served as settlement substrata and were attached with Velcro strips on the bottom of the containers. All tiles were positioned at $4 \mathrm{~cm}$ water depth and $8 \mathrm{~cm}$ below the cut-off filters. Due to changes in solar angle, the calculated exposure time for entire tiles to direct solar radiation was $4.5 \mathrm{~h}$ in May and July, $5 \mathrm{~h}$ in June, $2.5 \mathrm{~h}$ in August, $1 \mathrm{~h}$ in September and $0 \mathrm{~h}$ in October, whereas proportions of the tiles were exposed as long as $7.5 \mathrm{~h}$ in June and $2 \mathrm{~h}$ in October. During the bi-weekly cleaning procedure, closed cages were checked for intruding consumers and tiles were checked for accumulating sediment, which was then washed off.

UVR treatments. Different cut-off filters were chosen for the 4 light treatments. (1) The PAR treatment (400 to $700 \mathrm{~nm}$ ) was covered with a $4 \mathrm{~mm}$ Makrolon sheet (Long Life Plus 293, Röhm), which blocked radiation $<400 \mathrm{~nm}$ but allowed for $90 \%$ transmission of PAR. (2) The PAR + UVA treatment (320 to $700 \mathrm{~nm}$ ) was covered with a $3 \mathrm{~mm}$ Perspex sheet (GS 2648, Röhm) and a $0.1 \mathrm{~mm}$ clear polyester film (LTF Nashua Copy, Nashua), which together blocked radiation $<320 \mathrm{~nm}$ but transmitted $90 \%$ of PAR and UVA. The polyester film was exchanged monthly to prevent aging effects. (3) The PAR + UVA + UVB treatment (280 to $700 \mathrm{~nm}$ ) was covered with a $3 \mathrm{~mm}$ Perspex sheet, which transmitted $90 \%$ of solar radiation. (4) The full sunlight treatment had no filter and served as a control for filter artifacts in comparison with the PAR + UVA + UVB treatment. Optical properties of the cut-off filters (Fig. 1) were determined with a UV visible spectrophotometer (Cary3, Varian Optical Spectroscopy Instruments).

Radiation measurements. Solar radiation in the field was measured bi-weekly at solar noon with 3 broadband sensors (RM-21, Gröbel UV-Elektronik) for UVB ( 280 to $315 \mathrm{~nm}$ ), UVA (315 to $400 \mathrm{~nm}$ ) and PAR (400 to $700 \mathrm{~nm}$ ). Measurements were performed above the water surface and at $4 \mathrm{~cm}$ water depth. Readings from a local UVB monitoring station (Brewer MKIV 84, Halifax, data from World Ozone and UV radiation Data Center, North York, Ontario, Canada) served for comparison of seasonal changes in UVB flux.

Consumer abundance. Macrobenthic consumer abundance on the experimental plots was determined every 6 wk. The dominant consumers, gammarid amphipods, usually hid under experimental tiles. Therefore, rafts were brought to the beach and cautiously lifted out of the water in order to count consumers per experimental unit.

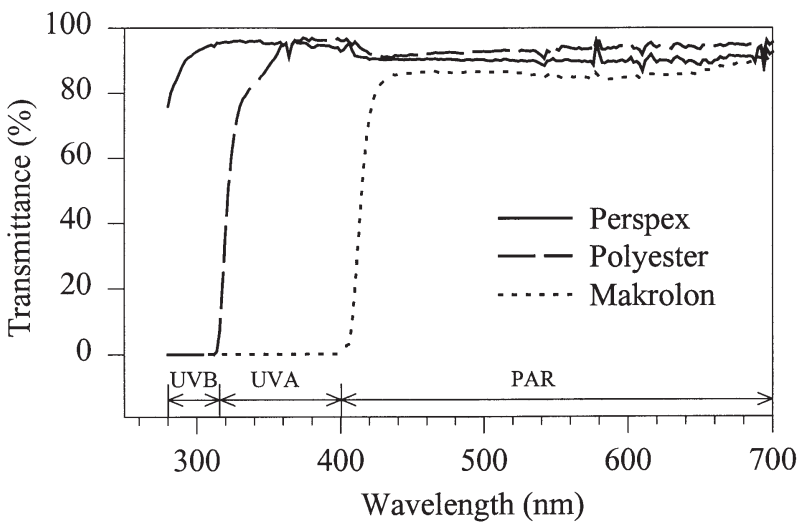

Fig. 1. Optical properties of cut-off filters for the different UV treatments: (1) Perspex = PAR + UVA + UVB, (2) Perspex + Polyester $=$ PAR + UVA, and (3) Makrolon $=$ PAR only

Community response. We analyzed macroscopic species composition and abundance on the experimental tiles on 10 July, 30 August and 15 October 2001. Percent cover of all species ( $>2 \mathrm{~mm}$ length) was estimated with a Plexiglas sheet marked with 50 random dots ( 1 dot $=2 \%$ cover $)$. For species identification, we used a portable stereomicroscope. In August, we also analyzed species composition and abundance of newly developing recruits $(>0.2 \mathrm{~mm}$ length). Recruit density was estimated in $6.3 \times 6.3 \mathrm{~mm}$ grids (3 subsamples per tile) using a stereomicroscope (16× magnification). Biomass of the entire community was measured as wet weight with a portable scale in the field. At the end of the experiment, all organisms were scraped from the tiles and dried for $48 \mathrm{~h}$ at $80^{\circ} \mathrm{C}$ to estimate dry weight. As measures of species diversity, we calculated the Shannon diversity index:

$$
H^{\prime}=-\sum_{i=1}^{k} \ln \left(p_{i}\right) \times p_{i}
$$

where $p_{i}$ is the cover of species $i$ divided by the total cover of $k$ species, species richness $\mathrm{S}$ (number of species per tile) and Pielou evenness $\left(H^{\prime} / \mathrm{lnS}\right)$.

Statistical analysis. Fixed-factor Repeated Measures (RM) ANOVA was used to test for the effects of consumers and UVR on biomass, total cover, total recruit density and diversity. Prior to analysis, percent cover data were angular-transformed and density data were log-transformed to achieve homogeneity of variances (Cochran's test). In July, percent cover data were not homogenous and therefore analyzed with a nonparametric Kruskal-Wallis test (Sokal \& Rohlf 1981). For the ANOVA results, relative effect sizes were calculated as percent variance explained (Howell 1992). Post-hoc multiple means comparisons were performed using the Tukey-Kramer procedure at $\alpha=0.05$ significance level. 
Table 1. Mean solar radiation $\left(\mathrm{W} \mathrm{m}^{-2}\right)$ at local noon measured bi-weekly above the water surface and at $4 \mathrm{~cm}$ water depth from June to October

\begin{tabular}{|lrrrr|}
\hline & \multicolumn{3}{c}{ Above surface } & \multicolumn{2}{c|}{4 cm depth } \\
& Mean & SE & Mean & \multicolumn{1}{c|}{ SE } \\
\hline UVB $(280$ to $315 \mathrm{~nm})$ & 0.07 & 0.01 & 0.04 & 0.01 \\
UVA (315 to $400 \mathrm{~nm})$ & 15.30 & 3.20 & 10.54 & 2.86 \\
PAR (400 to $700 \mathrm{~nm})$ & 231.29 & 72.90 & 124.46 & 54.19 \\
& & & & \\
\hline
\end{tabular}

Treatment effects on community structure were analyzed using 2 approaches. (1) We used MANOVA to analyze for interactive treatment effects on group composition of the community. We grouped species into red, brown and green algae, and invertebrates in order to reduce overall number of dependent variables and high variability of single species among treatments. We applied the Pillai trace statistics, which is very robust against violations of model assumptions (Johnson \& Field 1993, Scheiner 1993). The data were checked for univariate homogeneity of variances (Cochran's test). When MANOVA results were significant, effects on single groups were analyzed with protected ANOVA (Scheiner 1993), for which p-values were Bonferroni corrected. (2) Treatment effects on species composition and relative contributions of single species to shifts in community structure among the main treatments were explored with non-parametric ANOSIM and SIMPER procedures (PRIMER software, Plymouth Marine Laboratory), which are based on multi-dimensional scaling (MDS) of the Bray-Curtis dissimilarity index.

Table 2. Herbivore and carnivore abundance in the various consumer treatments (mean number $\pm 1 \mathrm{SE} 7 \times 7 \mathrm{~cm}^{-2}$, closed and half cages $\mathrm{n}=12$, open cages $n=24$ ). The dominant herbivore species was Gammarus oceanicus; other herbivores include the snail Lacuna vincta and the isopod Idotea baltica; carnivores include juvenile seastar Asterias vulgaris and juvenile green crab Carcinus maenas

\begin{tabular}{|c|c|c|c|c|c|c|}
\hline & \multicolumn{2}{|c|}{ Closed cages } & \multicolumn{2}{|c|}{ Half cages } & \multicolumn{2}{|c|}{ Open cages } \\
\hline & Mean & $\mathrm{SE}$ & Mean & SE & Mean & SE \\
\hline \multicolumn{7}{|l|}{ July } \\
\hline Gammarus & 0.08 & 0.08 & 1.75 & 0.33 & 1.29 & 0.20 \\
\hline Other herbivores & 0.00 & 0.00 & 0.08 & 0.08 & 0.04 & 0.04 \\
\hline Total consumer & 0.08 & 0.08 & 1.83 & 0.32 & 1.33 & 0.21 \\
\hline \multicolumn{7}{|l|}{ August } \\
\hline Gammarus & 7.00 & 1.95 & 13.58 & 1.92 & 5.96 & 0.66 \\
\hline Other herbivores & 0.08 & 0.08 & 0.25 & 0.13 & 0.63 & 0.17 \\
\hline Total consumer & 7.08 & 1.97 & 13.83 & 1.92 & 6.58 & 0.68 \\
\hline \multicolumn{7}{|l|}{ October } \\
\hline Gammarus & 0.58 & 0.19 & 8.42 & 1.35 & 6.25 & 0.93 \\
\hline Other herbivores & 0.00 & 0.00 & 0.08 & 0.08 & 0.04 & 0.04 \\
\hline Carnivores & 0.08 & 0.08 & 0.17 & 0.11 & 0.17 & 0.10 \\
\hline Total consumer & 0.67 & 0.19 & 8.67 & 1.34 & 6.46 & 0.93 \\
\hline
\end{tabular}

\section{RESULTS}

\section{Radiation measurements}

Average irradiances measured above the water surface and at $4 \mathrm{~cm}$ water depth during June to October are shown in Table 1 . On average, $58 \pm 10 \%$ of surface UVB, $56 \pm 9 \%$ of UVA and $39 \pm 10 \%$ of PAR reached the experimental treatments at $4 \mathrm{~cm}$ water depth, depending on turbidity. Different filter treatments successfully manipulated the light spectrum according to Fig. 1. Seasonal fluctuations of UVB in the region (Fig. 2) indicated that maximum UVB flux occurred in June and July.

\section{Consumer abundance}

In July, August and October, Gammarus oceanicus Segerstrale was the dominant consumer (Table 2). Total consumer densities significantly changed over time and with cage treatment (RM-ANOVA, Time $\times$ Cage Interaction, $\left.F_{4,60}=3.34, \mathrm{p}=0.016\right)$. Highest consumer densities were found in August and lowest in July (Table 2). In July and October, consumer abundance in open and half cages was similarly high indicating that there was no cage artifact, and consumer exclusion from closed cages was successful (Tukey-Kramer, p < 0.05). In August, half cages had significantly higher gammarid densities than open cages (Tukey-Kramer, p < 0.05). This was probably an effect of shelter, especially for small juveniles, which were abundant at this time of year. Recruitment of small gammarids within cages explains high consumer densities within closed cages in August (Table 2). Because closed cages were checked and cleaned bi-weekly, this likely had no long-term effect on macroscopic but possibly microscopic vegetation. There was no UV effect on consumer density (RM-ANOVA, radiation effect, $F_{3,40}=$ $0.92, \mathrm{p}=0.46)$.

\section{Effects on community biomass and abundance}

Overall, UVR and consumers both had significant effects on biomass, while total cover was affected by UVR but not by consumers. These effects all changed over the duration of the experiment as indicated by significant Time $\times$ Treatment interactions (Table 3A). The different radiation 


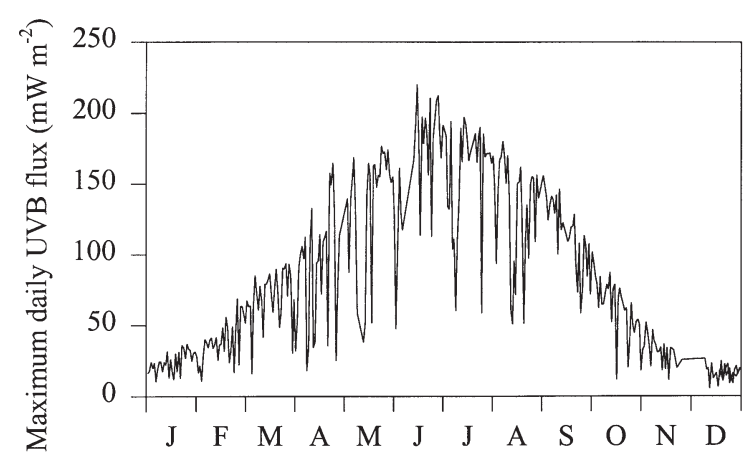

Fig. 2. Daily maximum CIE (Commission Internationale de L'Eclairage) erythemal weighted integral of UVB flux as measured by a nearby monitoring station (Brewer, Halifax, data from World Ozone and UV radiation Data Center, Canada)

treatments significantly affected biomass and total cover, and these effects also changed over time (Table 3B). Strong treatment effects occurred in July, but no or weak effects occurred in August and October.

The only macroscopic colonizer during the first $6 \mathrm{wk}$ of our experiment was the annual brown alga Pilayella littoralis Kjellm. This species reached high biomass and cover on experimental tiles in July. UVR significantly suppressed biomass of P. littoralis (Fig. 3A). Consumers had no effect when UVR was present, but favored P. littoralis biomass when UVR was excluded (Fig. 3A). This significant UVR $\times$ Consumer Interaction (ANOVA, $\left.F_{2,25}=8.65, \mathrm{p}=0.0014\right)$ explained $8 \%$ of the

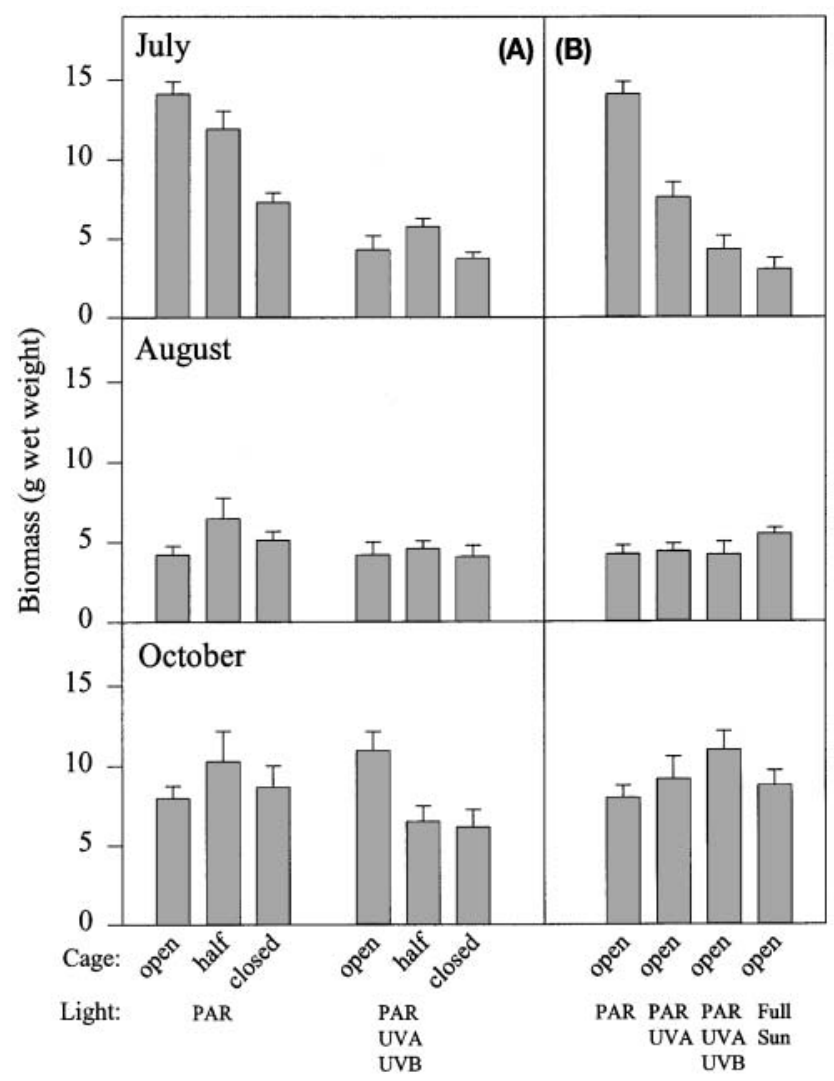

Fig. 3. Effects of (A) UV radiation (PAR vs PAR + UVA + UVB) and consumers (open, half, closed cages), and (B) radiation treatments on total biomass in July, August and October (mean $\pm 1 \mathrm{SE}, \mathrm{n}=6)$. Water temperature was $8.7^{\circ} \mathrm{C}( \pm 0.95)$ in July, $14.2^{\circ} \mathrm{C}( \pm 1.26)$ in August and $17.1^{\circ} \mathrm{C}( \pm 1.07)$ in October

Table 3. Repeated Measures ANOVA on (A) UVR and consumer effects and (B) radiation effects on percent cover and wet weight biomass (July, August and October), and species diversity $H^{\prime}$ (August and October). Percent cover data were angulartransformed $(\mathrm{n}=6)$

\begin{tabular}{|c|c|c|c|c|c|c|c|c|c|c|}
\hline \multirow[t]{2}{*}{ Source } & \multirow[t]{2}{*}{$\mathrm{df}$} & \multicolumn{3}{|c|}{ Wet biomass } & \multicolumn{3}{|c|}{ Total cover } & \multicolumn{3}{|c|}{ Diversity $H^{\prime}$} \\
\hline & & MS & $F$ & $\mathrm{p}$ & MS & $F$ & $\mathrm{p}$ & MS & $F$ & $\mathrm{p}$ \\
\hline \multicolumn{11}{|l|}{ (A) } \\
\hline UVR & 1 & 223.05 & 44.13 & $<0.0001$ & 0.79 & 14.25 & 0.0008 & 0.01 & 0.01 & 0.9078 \\
\hline Consumer (C) & 2 & 37.47 & 7.41 & 0.0029 & 0.03 & 0.49 & 0.6159 & 0.02 & 0.09 & 0.9117 \\
\hline UVR:C & 2 & 7.70 & 1.52 & 0.2374 & 0.01 & 0.05 & 0.9466 & 0.20 & 1.04 & 0.3696 \\
\hline Block & 5 & 5.99 & & & 0.01 & & & 0.26 & & \\
\hline Residuals & 25 & 5.05 & & & 0.06 & & & 0.19 & & \\
\hline Time & 2 & 138.13 & 24.04 & $<0.0001$ & 2.05 & 54.70 & $<0.0001$ & 24.24 & 173.26 & $<0.0001$ \\
\hline Time:UVR & 2 & 90.14 & 15.69 & $<0.0001$ & 0.51 & 13.68 & $<0.0001$ & 0.05 & 0.36 & 0.5507 \\
\hline Time:C & 4 & 15.26 & 2.66 & 0.0414 & 0.07 & 1.93 & 0.1172 & 0.05 & 0.34 & 0.7126 \\
\hline Time:UVR:C & 4 & 31.85 & 5.54 & 0.0007 & 0.08 & 2.15 & 0.0853 & 0.08 & 0.57 & 0.5689 \\
\hline Residuals & 60 & 5.75 & & & 0.04 & & & 0.14 & & \\
\hline \multicolumn{11}{|l|}{ (B) } \\
\hline Radiation (R) & 3 & 29.81 & 8.35 & 0.0016 & 0.23 & 10.13 & 0.0006 & 0.01 & 0.05 & 0.9837 \\
\hline Block & 5 & 4.14 & & & 0.04 & & & 0.08 & & \\
\hline Residuals & 15 & 3.57 & & & 0.02 & & & 0.28 & & \\
\hline Time & 2 & 129.52 & 26.65 & $<0.0001$ & 1.11 & 33.92 & $<0.0001$ & 15.09 & 110.02 & $<0.0001$ \\
\hline Time:R & 6 & 65.22 & 13.42 & $<0.0001$ & 0.28 & 8.53 & $<0.0001$ & 0.08 & 0.60 & 0.6228 \\
\hline Residuals & 40 & 4.86 & & & 0.03 & & & 0.14 & & \\
\hline
\end{tabular}




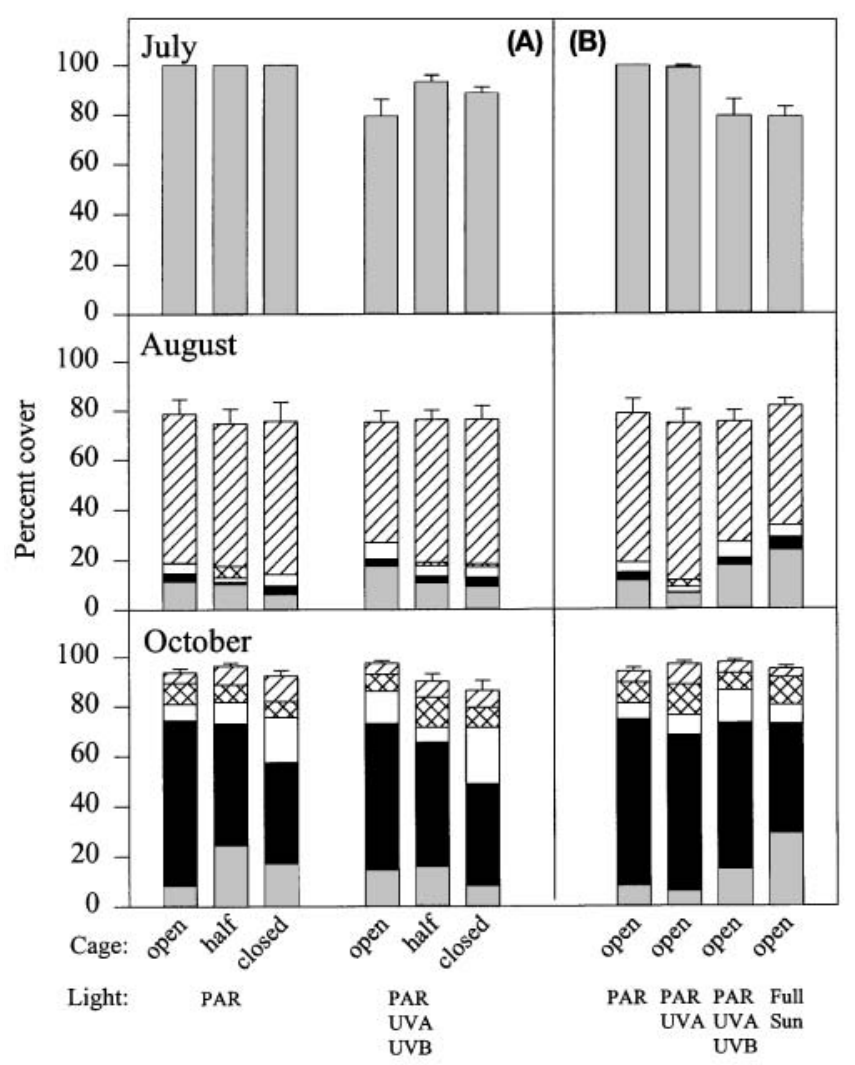

Fig. 4. Effects of (A) UV radiation (PAR vs PAR + UVA + UVB) and consumers (open, half, closed cages), and (B) radiation treatments on total cover (mean $\pm 1 \mathrm{SE}, \mathrm{n}=6$ ) and taxonomic group composition in July, August and October. Different colors and fills represent the following taxonomic groups: brown algae (gray), red algae (black), green algae (white), sessile invertebrates (cross-hatched) and diatoms (diagonal-hatched)

variance, as compared to a strong main UVR effect (58\%) and a weaker main consumer effect (14\%). Biomass in open and half cages was not significantly different (Tukey-Kramer, p > 0.5), suggesting that there were no cage artifacts. When exposed to different radiation treatments, biomass of $P$. littoralis strongly decreased from $\mathrm{PAR}>\mathrm{PAR}+\mathrm{UVA}>\mathrm{PAR}+\mathrm{UVA}+$ UVB (Fig. 3B, Tukey-Kramer, $\mathrm{p}<0.05$ ). The radiation effect (ANOVA, $F_{3,15}=30.65, \mathrm{p}<0.0001$ ) explained $80 \%$ of the variance. The PAR + UVA + UVB treatment did not differ from the full sun treatment indicating that there were no filter artifacts (Tukey-Kramer, $\mathrm{p}>0.05)$. Similarly to biomass, total cover of $P$. littoralis in July was significantly reduced by UVR, which was an effect of UVB rather than UVA (Fig. 4A,B; KruskalWallis, radiation effect $H_{3,15}=19.08, p=0.0003$ ). However, UVR and radiation effects on cover were not as strong as on biomass. There was no main consumer effect on total cover (Kruskal-Wallis test, $H_{2,15}=1.23$, $\mathrm{p}=0.54$ ), but a slight UVR $\times$ Consumer Interaction
(Kruskal-Wallis, UVR effect on the difference between open vs closed treatments, $H_{1,15}=5.23, \mathrm{p}=0.022$ ).

By the end of August, a variety of brown, red and green algae as well as invertebrates recruited on the tiles, but were embedded in a thick diatom mat (Fig. 4). Community biomass was low compared to July and October (Fig. 3). We did not detect any significant treatment effects on biomass or total cover in August (Figs. $3 \& 4$; ANOVA, p > 0.05). Similarly, total recruit density in the microscopic community was unaffected by UVR or radiation effects (Fig. 5A,B; ANOVA, UVR effect, $F_{1,25}=0.66, \mathrm{p}=0.42$; radiation effect, $F_{3,15}=2.65$, $\mathrm{p}=0.086)$, but consumer presence slightly increased recruit density (ANOVA, $F_{2,25}=4.49, \mathrm{p}=0.021$ ). There were no cage artifacts in this analysis (Tukey-Kramer, $\mathrm{p}>0.05)$.

Towards October, the diatom mat had decreased, and further macroalgae had recruited and grown to visible size (Figs. $3 \& 4$ ). There was a slightly significant UVR $\times$ Consumer Interaction on wet as well as dry weight biomass which explained $14 \%$ of the variance in both cases (ANOVA, effects on wet weight $F_{2,25}=$ $3.84, \mathrm{p}=0.035$; on dry weight $F_{2,25}=4.31, \mathrm{p}=0.025$ ). This interaction effect was caused by increased biomass in open cages under UV exposure compared to half and closed cages, while no such patterns occurred in the PAR treatments (Fig. 3A). However, there was no radiation effect on wet or dry weight (Fig. 3B; ANOVA, effects on wet weight, $F_{3,15}=1.57, \mathrm{p}=0.24$; on dry weight, $F_{3,15}=1.38, \mathrm{p}=0.29$ ). Conversion of wet weight was $7.60( \pm 0.12) \times$ dry weight. In contrast to biomass (Fig. 3), there were no UVR, radiation or consumer effects on total cover in October (Fig. 4; ANOVA, $\mathrm{p}>0.5$ ).

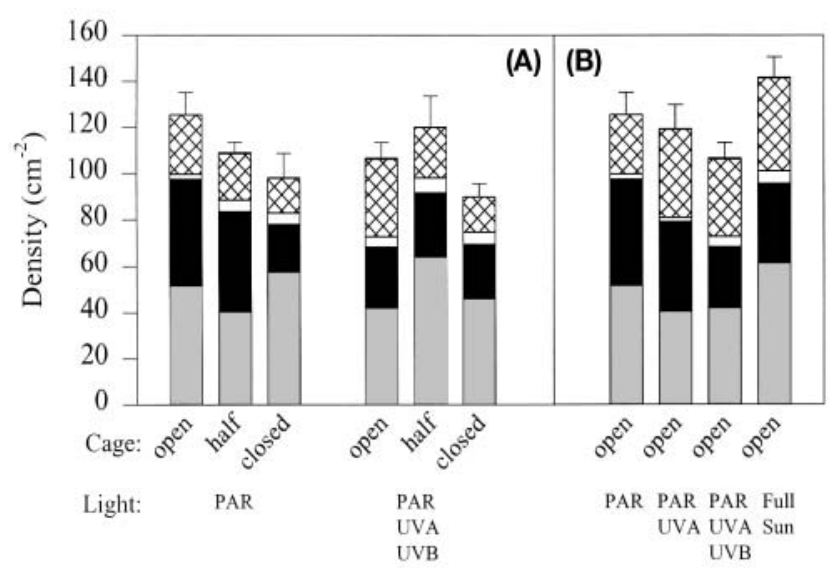

Fig. 5. Effects of (A) UV radiation (PAR vs PAR + UVA + UVB) and consumers (open, half, closed cages), and (B) radiation treatments on total density (mean $\pm 1 \mathrm{SE}, \mathrm{n}=6$ ) of microscopic recruits $(>0.2 \mathrm{~mm})$ and taxonomic group composition in August. Colors and fills as in Fig. 4 
Table 4. MANOVA results on (A) UVR and consumer effects and (B) radiation effects on group composition (brown, red, green algae and invertebrates) in August and October, and on recruit group composition in August. Cover data were angular and recruit densities log-transformed $(n=6)$

\begin{tabular}{|llcccc|}
\hline & Source & df & Pillai Trace & $F$ & $\mathrm{p}$ \\
\hline (A) & & & & & \\
August & UVR & 4,22 & 0.036 & 0.208 & 0.9310 \\
& Consumer (C) & 8,46 & 0.293 & 0.989 & 0.4564 \\
& UVR:C & 8,46 & 0.154 & 0.479 & 0.8642 \\
Recruits & UVR & 4,22 & 0.421 & 4.012 & 0.0136 \\
& Consumer & 8,46 & 0.675 & 2.929 & 0.0099 \\
& UVR:C & 8,46 & 0.791 & 3.768 & 0.0018 \\
October & UVR & 4,22 & 0.102 & 0.631 & 0.6454 \\
& Consumer & 8,46 & 0.586 & 2.388 & 0.0303 \\
& UVR:C & 8,46 & 0.199 & 0.636 & 0.7433 \\
(B) & & & & & \\
August & Radiation & 12,42 & 0.408 & 0.789 & 0.6276 \\
Recruits & Radiation & 12,42 & 1.412 & 3.115 & 0.0031 \\
October & Radiation & 12,42 & 1.175 & 2.255 & 0.0259 \\
& & & & & \\
\hline
\end{tabular}

\section{Species diversity and composition}

Altogether we found: 5 brown algae (Chordaria flagelliformis Agardh, Petalonia fascia Kuntze, Pilayella littoralis, Ectocarpus fasciculatus Harv. and Fucus vesiculosus L.); 7 green algae (Acrosiphonia arcta Agardh., Enteromorpha intestinalis Link, Ulva lactuca L., Cladophora rupestris Kuetz., Cladophora albida Kuetz., Chaetomorpha linum Kuetz. and Ulothrix flacca Thuret); 6 red algae (Ceramium nodulosum Ducluzeau, Polysiphonia harveyi Bailey, Callithamnion tetragonum S. F. Gray, Bonnemaisonia hamifera Hariot with its tetrasporic phase Trailliella intricata Batters, Cystoclonium purpureum Batters and Dumontia con- torta Rupr.); and 2 invertebrates, the hydrozoan Obelia sp. and the blue mussel Mytilus edulis L., settling on the experimental tiles.

Species diversity, species richness and evenness significantly increased from August to October but were not affected by UVR, consumers or radiation treatments (Table 3A,B). Diversity $H^{\prime}$ was $0.56 \pm 0.05$ (mean $\pm 1 \mathrm{SE}, \mathrm{n}=48$ ) in August and $1.80 \pm 0.03$ in October, species richness S was $2.68 \pm 0.22$ in August and $9.94 \pm$ 0.20 in October, and Pielou evenness was $0.59 \pm 0.02$ in August and $0.79 \pm 0.01$ in October. Among microscopic recruits in August, diversity was $1.86 \pm 0.02$, species richness $10.89 \pm 0.22$ and evenness $0.78 \pm 0.01$. Despite lacking effects on diversity, multivariate analyses revealed significant treatment effects on community group and species composition.

In August, the macroscopic community was dominated by the brown alga Chordaria flagelliformis, which was embedded in a thick diatom mat (Fig. 4A,B). UVR and consumer treatments as well as radiation treatments did not affect group (Table $4 \mathrm{~A}, \mathrm{~B}$ ) or species composition (ANOSIM, p > 0.5). Among microscopic recruits in August, however, group composition was affected by a strong UVR $\times$ Consumer Interaction (Fig. 5A, Table 4A). Red algae were favored by consumers but inhibited by UVR (ANOVA, consumer effect, $F_{2,25}=8.15, \mathrm{p}=0.0019$; UVR effect, $F_{1,25}=6.45$, $\mathrm{p}=0.017$ ), brown algae were affected by a UVR $\times$ Consumer Interaction $\left(\mathrm{ANOVA}, F_{2,25}=7.54, \mathrm{p}=0.0027\right.$ ) and invertebrates were favored by consumers (ANOVA, $\left.F_{2,25}=4.96, \mathrm{p}=0.015\right)$. SIMPER analysis revealed that the most abundant red alga Ceramium nodulosum, brown algae Petalonia fascia and Fucus vesiculosus, and the invertebrate Mytilus edulis together explained over $60 \%$ of the dissimilarities between communities of different UVR and consumer treatments (Table 5).

Table 5. Results of ANOSIM (Global R, p) on macroscopic and microscopic species composition in August and October, and SIMPER results on the percent contribution of single species to total dissimilarity in species composition due to treatment effects $(B=$ brown, $\mathrm{R}=$ red, $\mathrm{G}=$ green algae and $\mathrm{I}=$ invertebrates). Percent contributions are averaged over all significant pair-wise treatment comparisons. The direction of the effect is given as $+=$ positive, $-=$ negative, $\pm=$ inconsistent and $\mathrm{nc}=$ no contribution

\begin{tabular}{|c|c|c|c|}
\hline & UVR effect & Consumer effect & Radiation effect \\
\hline Macroscopic August & $\mathrm{R}=-0.1, \mathrm{p}=0.96$ & $\mathrm{R}=-0.07, \mathrm{p}=0.88$ & $\mathrm{R}=0.08, \mathrm{p}=0.125$ \\
\hline Microscopic August & $\mathrm{R}=0.166, \mathrm{p}=0.003$ & $\mathrm{R}=0.102, \mathrm{p}=0.015$ & $\mathrm{R}=0.237, \mathrm{p}=0.001$ \\
\hline B Petalonia fascia & $19.6 \%+$ & $19.2 \%-$ & $10.8 \%+$ \\
\hline B Fucus vesiculosus & $16.7 \% \quad-$ & $14.7 \%+$ & $18.3 \% \pm$ \\
\hline R Ceramium nodulosum & $15.6 \% \quad-$ & $16.9 \%+$ & $21.5 \% \quad-$ \\
\hline I Mytilus edulis & $14.4 \%+$ & $19.6 \%+$ & $16.7 \%+$ \\
\hline Macroscopic October & $\mathrm{R}=-0.035, \mathrm{p}=0.72$ & $\mathrm{R}=0.134, \mathrm{p}=0.016$ & $\mathrm{R}=0.150, \mathrm{p}=0.039$ \\
\hline B Chordaria flagelliformis & nc & $11.1 \%+$ & $30.1 \%+$ \\
\hline B Ectocarpus fasciculatus & $\mathrm{nc}$ & $10.2 \% \quad-$ & nc \\
\hline R Polysiphonia harveyi & nc & $24.2 \%+$ & $20.5 \% \quad-$ \\
\hline $\mathrm{R}$ Trailliella intricata & nc & $\mathrm{nc}$ & $10.1 \% \quad-$ \\
\hline G Acrosiphonia arcta & nc & $14.1 \% \quad-$ & $\mathrm{nc}$ \\
\hline
\end{tabular}


Radiation treatments also significantly affected recruit group composition (Fig. 5B, Table 4B). Red algae were negatively affected by UVR, especially UVB (ANOVA, $F_{3,15}=9.71, \mathrm{p}=0.00083$; Tukey-Kramer, $\left.\mathrm{p}<0.0125\right)$, while green algae tended to be favored in the full sun treatment $\left(F_{3,15}=4.23, \mathrm{p}=0.023\right.$; Tukey-Kramer, $\mathrm{p}<$ 0.0125). SIMPER analysis corroborated the negative UV effects on the red alga $C$. nodulosum, but did not detect contributions of any single green algae (Table 5). UV effects on F. vesiculosus were inconsistent in direction: $F$. vesiculosus recruits increased in PAR + UVA + UVB but decreased in Full sunlight treatments compared to PAR and PAR + UVA treatments.

In October, macroscopic group composition was slightly affected by consumers (Fig. 4A, Table 4A), because of a positive consumer effect on red algae (ANOVA, $F_{2,25}=4.23, \mathrm{p}=0.026$ ). SIMPER analysis revealed that the most abundant red alga Polysiphonia harveyi contributed most to this consumer effect on species composition (Table 5). Radiation treatments significantly affected group composition (Fig. 4B, Table 4B) and species composition (Table 5) with positive UV effects on the brown algae Chordaria flagelliformis and negative effects on the red algae $P$. harveyi (Table 5).

\section{DISCUSSION}

Our experiments revealed strong and interactive effects of UV radiation and consumers on productivity of the early colonizing brown alga Pilayella littoralis and on species composition of microscopic recruits. Thereby UVB had more pronounced negative effects than UVA. These effects, however, diminished during later stages of succession.

\section{UV effects}

During the first 6 wk of our experiment, biomass of the early successional brown alga Pilayella littoralis was strongly suppressed by UV radiation. This effect was less pronounced on total cover of this species, suggesting that either growth of $P$. littoralis was suppressed in UV exposed treatments or that germination of spores, and thus initiation of growth, was delayed. Similarly, high initial sensitivity to UVB was reported for the filamentous brown alga Ectocarpus rhodochondroides (Santas et al. 1998a), where strong initial UV effects on productivity diminished over time. The authors suggested that spore germination was inhibited while developing sporophytes adapted to UVB exposure (Santas et al. 1998a). In kelps, zoospores were shown to suffer from inhibition of photosynthesis, loss of viability and DNA damage when exposed to UV stress, and their sensitivity was related to the depth where parental sporophytes occurred and thus to pre-acclimatization (Wiencke et al. 2000). Moreover, Hanelt et al. (1997a) reported that the capacity to cope with high light stress increased with increasing age of Laminaria sporophytes, a process related to increases in pigment concentrations and changes in thallus structure. As shown for other environmental factors (Lotze et al. 1999, 2001, Coelho et al. 2000, Lotze \& Worm 2000), early life stages appear to be more sensitive to UV stress compared with adults, but may have the capacity to adapt as they mature. In contrast to Santas et al. (1998a), who observed rapid recovery of E. rhodochondroides, productivity of $P$. littoralis remained reduced under natural UV exposure in our experiments.

Strong UV effects in July diminished over time. We found no UV effects on biomass, total cover, total recruit density or species diversity in August and only weak effects in October. Several factors could explain this pattern. UV radiation and direct exposure to sunlight constantly decreased after reaching their peak in June to July (Fig. 2) reducing UV and high PAR stress as the experiment progressed. On the other hand, species recruiting in summer either might have been less UV sensitive than early colonizing Pilayella littoralis, or they adapted to UV stress by developing protective or repair mechanisms as they matured (see above, Hanelt et al. 1997a). Increasing water temperature may have enhanced development of photoprotective features (Franklin \& Forster 1997). Furthermore, diatom mats in August could have protected recruits from UV exposure as shown for sediment-inhabiting species (Vinebrooke \& Leavitt 1999).

In spite of lacking effects on aggregate parameters, UV radiation changed group and species composition of microscopic recruits in August and also, but less pronounced, of the macroscopic community in October. Negative UV effects were most pronounced in the red algae Ceramium nodulosum and Polysiphonia harveyi. However, although UV sensitive, these algae did settle and develop in UV-exposed treatments over the long term. Harmful UV effects on red algae may have favored other colonizing species. We found positive UV effects on recruits of the brown alga Petalonia fascia and partly Fucus vesiculosus and the invertebrate Mytilus edulis in August, as well as positive UV effects on the brown alga Chordaria flagelliformis in October. Compared to the more sensitive red algae that occur in deeper waters or understory, these brown algae commonly occur in the intertidal or shallow subtidal and are likely to be more tolerant to natural UV stress (Dring et al. 1996b, Hanelt et al. 1997b, Bischof et al. 1998). 


\section{Consumer effects}

Effects of the dominant herbivore Gammarus oceanicus on macroalgal biomass and cover were weak and often positive. Consumers favored biomass development of Pilayella littoralis in July, when UV was excluded. These positive consumer effects were observed on biomass (i.e. growth) and not on cover (i.e. abundance); thus, we assume a fertilizing effect on algal growth through excretion (Sterner 1986, Sommer 1997). Since there were no cage artifacts in the analysis, the positive consumer effect cannot be explained by decreased sedimentation or increased water flow in open compared to half and closed cages. In August and October, consumer effects on total biomass and cover were weak. Gammarid amphipods such as G. oceanicus are macrophagous grazers known to feed on a variety of perennial and annual macroalgae as well as on diatoms (Denton \& Chapman 1991, Parker et al. 1993). Gammarus locusta was shown to heavily feed on filamentous green and brown algal recruits (Lotze \& Worm 2000). Thus, we would have expected overall stronger and negative consumer effects in our experiments. However, consumers had significant effects on species composition in August and October. Consumers suppressed the filamentous brown algae Petalonia fascia and Ectocarpus fasciculatus and the green alga Acrosiphonia arcta, whereas red and leathery brown algae as well as invertebrates were favored by consumer presence.

\section{Interactions of UV and consumer effects}

Interactions between UV radiation and consumer effects can occur when UV-induced changes in the chemical composition of algae alter consumption patterns. For example, UV exposure can reduce concentrations of defense chemicals and enhance palatability (Cronin \& Hay 1996), or enhance the production of herbivore deterrents such as phlorotannins (Pavia et al. 1997). On the other hand, UV radiation can directly harm invertebrate grazers, which may enhance algal productivity (Bothwell et al. 1994, Vinebrooke \& Leavitt 1999). We found strong UV $\times$ Consumer Interactions on biomass in July, and a slightly significant interaction on biomass in October. However, none of these effects could be explained by the above-mentioned processes. In July, biomass development and cover of Pilayella littoralis was clearly suppressed under UV exposure, and consumer presence favored algal biomass only when UV radiation was excluded (see above). In October, biomass under UV exposure was higher in open compared to half and closed cages, while no such pattern occurred when UV was ex- cluded. Since there was no UVR or radiation effect on biomass and no UV effect on consumers, we assume this to be a spurious effect.

In addition to effects on productivity of Pilayella littoralis, we found species- and group-specific responses to both UV and consumers that led to interactive effects on species composition, especially among recruits in August. Sessile invertebrates (Mytilus edulis) and some leathery brown algae (Chordaria flagelliformis and Fucus vesiculosus) were unaffected or favored by both UV exposure and consumers. In contrast, all other groups were suppressed either by UV (red algae, P. littoralis) or consumers (green algae, Petalonia fascia and Ectocarpus fasciculatus). Therefore, changing UV radiation and consumer pressure have the potential to cause seasonal shifts in species composition and community structure.

In conclusion, our results show that early colonizing species and microscopic recruits are particularly sensitive to UV and consumer effects. As species mature, adaptation and protection against inhibitory UV radiation and herbivory may diminish these effects over time (this paper, Santas et al. 1998a,b). Pronounced species-specific and life-stage specific sensitivities towards UV and consumers can result in spatial or seasonal shifts in the distribution and abundance of species on rocky shores.

Acknowledgements. We thank John Cullen for insights and discussions. Lise Chapman, Dave and Scan Chaisson kindly assisted in the field. We gratefully acknowledge financial support by the German Research Council (DFG Lo 819/1-1) to H.K.L. and Proklima International (GTZ), Windhoek, Namibia, to M.W.

\section{LITERATURE CITED}

Beardall J, Beer S, Raven JA (1998) Biodiversity of marine plants in an era of climate change: some predictions based on physiological performance. Bot Mar 41:113-123

Bischof K, Hanelt D, Wiencke C (1998) UV-radiation can affect depth-zonation of Antarctic macroalgae. Mar Biol 131:597-605

Bothwell ML, Sherbot DMJ, Pollock CM (1994) Ecosystem response to solar ultraviolet-B radiation: influence of trophic-level interactions. Science 265:97-100

Coelho SM, Rijstenbil JW, Brown MT (2000) Impacts of anthropogenic stresses on the early development stages of seaweeds. J Aquat Ecosyst Stress Recovery 7:317-333

Cronin G, Hay ME (1996) Susceptibility to herbivores depends on recent history of both the plant and the animal. Ecology 77:1531-1543

Crutzen PJ (1992) Ultraviolet on the increase. Nature 356: 104-105

Cullen JJ, Neale PJ (1994) Ultraviolet radiation, ozone depletion, and marine photosynthesis. Photosynth Res 39: 303-320

Denton AD, Chapman ARO (1991) Feeding preferences of gammarid amphipods among four species of Fucus. Mar Biol 109:503-506 
Döhler G, Hagmeier E, David C (1995) Effects of solar and artificial UV irradiation on pigments and assimilation of $15 \mathrm{~N}$ ammonium and $15 \mathrm{~N}$ nitrate by macroalgae. J Photochem Photobiol B Biol 30:179-187

Dring MJ, Makarov V, Schoschina E, Lorenz M, Lüning K (1996a) Influence of ultraviolet-radiation on chlorophyll fluorescence and growth in different life-history stages of three species of Laminaria (Phaeophyta). Mar Biol 126: 183-191

Dring MJ, Wagner A, Boeskov J, Lüning K (1996b) Sensitivity of intertidal and subtidal red algae to UVA and UVB radiation, as monitored by chlorophyll fluorescence measurements: influence of collection depth and season, and length of irradiation. Eur J Phycol 31:293-302

Franklin LA, Forster RM (1997) The changing irradiance environment: consequences for marine macrophyte physiology, productivity and ecology. Eur J Phycol 32:207-232

Hanelt D, Wiencke C, Karsten U, Nultsch W (1997a) Photoinhibition and recovery after high light stress in different developmental and life-history stages of Laminaria saccharina (Phaeophyta). J Phycol 33:387-395

Hanelt D, Wiencke C, Nultsch W (1997b) Influence of UV radiation on the photosynthesis of Arctic macroalgae in the field. J Photochem Photobiol B Biol 38:40-47

Howell DC (1992) Statistical methods for psychology. Duxbury Press, Belmont, CA

Johnson CR, Field CA (1993) Using fixed-effects model multivariate analysis of variance in marine biology and ecology. Oceanogr Mar Biol Annu Rev 31:177-221

Keizer P, Budgen G, Subba Rao D, Strain P (1996) Long-term monitoring program: Indian Point and Sambro, Nova Scotia, for the period July 1992 to December 1994. Can Data Rep Fish Aquat Sci 980

Kerr JB, McElroy CT (1993) Evidence for large upward trends of ultraviolet-B radiation linked to ozone depletion. Science 262:1032-1034

Larkum AWD, Wood WF (1993) The effect of UV-B radiation on photosynthesis and respiration of phytoplankton, benthic macroalgae and seagrasses. Photosynth Res 36: 17-23

Lotze HK, Worm B (2000) Variable and complementary effects of herbivores on different life stages of bloom-forming macroalgae. Mar Ecol Prog Ser 200:167-175

Lotze HK, Worm B (2002) Complex interactions of climatic and ecological controls on macroalgal recruitment. Limnol Oceanogr 47:1734-1741

Lotze HK, Schramm W, Schories D, Worm B (1999) Control of macroalgal blooms at early developmental stages: Pilayella littoralis versus Enteromorpha spp. Oecologia 119: $46-54$

Editorial responsibility: Otto Kinne (Editor),

Oldendorf/Luhe, Germany
Lotze HK, Worm B, Sommer U (2001) Strong bottom-up and top-down control of early life stages of macroalgae. Limnol Oceanogr 46:749-757

Parker T, Johnson C, Chapman ARO (1993) Gammarid amphipods and littorinid snails have significant but different effects on algal succession in littoral fringe tidepools. Ophelia 38:69-88

Pavia H, Cervin G, Lindgren A, Åberg P (1997) Effects of UV$\mathrm{B}$ radiation and simulated herbivory on phlorotannins in the brown alga Ascophyllum nodosum. Mar Ecol Prog Ser 157:139-146

Rozema J, Van de Staaij J, Bjoern LO, Caldwell M (1997) UV$\mathrm{B}$ as an environmental factor in plant life: stress and regulation. Trends Ecol Evol 12:22-28

Santas R, Korda A, Lianou C, Santas P (1998a) Community responses to UV radiation. 1. Enhanced UVB effects on biomass and community structure of filamentous algal assemblages growing in a coral reef mesocosm. Mar Biol 131: 153-162

Santas R, Santas P, Lianou C, Korda A (1998b) Community responses to UV radiation. 2. Effects of solar UVB on fieldgrown diatom assemblages of the Carribean. Mar Biol 131:163-171

Scheiner SM (1993) MANOVA: multiple response variables and multispecies interactions. In: Scheiner SM, Gurevitch $\mathrm{J}$ (eds) Design and analysis of ecological experiments. Chapman \& Hall, New York, p 94-112

Searles PS, Flint SD, Caldwell MM (2001) A meta-analysis of plant field studies simulating stratospheric ozone depletion. Oecologia 127:1-10

Sokal RR, Rohlf FJ (1981) Biometry. WH Freeman, New York

Sommer U (1997) Selectivity of Idothea chelipes (Crustacea: Isopoda) grazing on benthic microalgae. Limnol Oceanogr 42:1622-1628

Sterner RW (1986) Herbivores' direct and indirect effects on algal populations. Science 231:605-607

Vincent WF, Roy S (1993) Solar ultraviolet-B radiation and aquatic primary production: damage, protection, and recovery. Environ Rev 1:1-12

Vinebrooke RD, Leavitt PR (1999) Differential responses of littoral communities to ultraviolet radiation in an alpine lake. Ecology 80:223-237

Wiencke C, Gomez I, Pakker H, Flores-Moya A, Altamirano M, Hanelt D, Bischof K, Figueroa FL (2000) Impact of UVradiation on the viability, photosynthetic characteristics and DNA of brown algal zoospores: implications for depth zonation. Mar Ecol Prog Ser 197:217-229

Worm B (2000) Consumer versus resource control in rocky shore food webs: Baltic Sea and NW Atlantic Ocean. Ber Inst Meereskd Christian-Albrechts-Univ Kiel 316:1-147

Submitted: March 19, 2002; Accepted: July 26, 2002

Proofs received from author(s): October 22, 2002 